\title{
Copper chaperone cycling and degradation in the regulation of the cop operon of Enterococcus hirae
}

\author{
David Magnani \& Marc Solioz* \\ Department of Clinical Pharmacology, University of Berne, CH-3010, Berne, Switzerland; *Author for \\ correspondence (Fax: +41-31-6324997; E-mail: marc.solioz@ikp.unibe.ch)
}

Key words: ATPase, bacteria, copper, Enterococcus hirae, evolution, regulation, repressor, surface plasmon resonance

\begin{abstract}
Extensive insight into copper homeostasis has recently emerged. The Gram-positive bacterium Enterococcus hirae has been a paradigm for many aspects of the process. The cop operon of E. hirae consists of four genes that encode a repressor, CopY, a copper chaperone, CopZ, and two CPx-type copper ATPases, CopA and CopB. CopA and CopB accomplish copper uptake and export, respectively, and the expression of the cop operon is regulated by copper via the CopY repressor and the CopZ chaperone. The functions of the four Cop proteins have been extensively studied in vivo as well as in vitro and a detailed understanding of the regulation of the cop operon by copper has emerged.
\end{abstract}

\section{Introduction}

Copper serves as a cofactor for many enzymes due to its biologically suitable redox potential. However, copper excess can lead to toxic effects. Cellular copper levels must therefore be tightly regulated in all organisms. Copper homeostasis in Enterococcus hirae has been extensively studied and reviewed (Solioz 2001; Lu \& Solioz 2002; Solioz \& Stoyanov 2002, 2003; Wimmer et al. 2002; Lu et al. 2003). It is currently the best understood prokaryotic copper homeostatic system. It consists of four genes $\operatorname{cop} Y, \operatorname{cop} Z, \operatorname{cop} A$ and $\operatorname{cop} B$, arranged in the cop operon. The gene products of $\operatorname{cop} A$ and $c o p B$ are copper transporting ATPases, cop $Y$ encodes a copper responsive repressor, and cop $Z$ codes for a chaperone which serves in intracellular copper routing (Odermatt et al. 1993; Odermatt \& Solioz 1995). The cop operon allows growth of $E$. hirae in copper-limiting conditions as well as in up to $8 \mathrm{mM}$ copper. According to the current model, CopA takes up copper when it is limiting, CopB extrudes excess copper, CopY regulates expression of the cop operon and
CopZ transfers copper intracellularly, e.g. to the CopY repressor (Odermatt et al. 1994; WunderliYe \& Solioz 1999).

\section{Evolution of copper ATPases}

CopA and CopB belong to the P1 subclass of the P-type ATPases (Lutsenko \& Kaplan 1995). Because of the conspicuous feature of the intramembranous CPC or CPH motif (sometimes also SPC) of heavy metal ATPases, it has also been suggested to call them CPx-type ATPases (Solioz \& Vulpe 1996). The CPx motif is located in the middle of the predicted membrane helix 6 in the most conserved core structure of the enzyme and apparently constitutes part of the ion channel through the membrane. Copper ATPases have been surprisingly conserved from bacteria to humans. Recently, the oldest known microfossils have been discovered in 3.2 billion year old deepsea volcanic rock (Rasmussen 2000). This suggests that the first living organisms on earth evolved around hydrothermal vents. The hot, acidic 
seawater at these vents releases heavy metal ions (Zierenberg et al. 2000) and resistance to these metal ions would have been an evolutionary priority for early life. The first heavy metal ATPases may thus have served in the detoxification of the cellular cytoplasm. Early evolution of heavy metal ATPases is supported by the high conservation of these enzymes across phyla and the divergences of heavy metal and on non-heavy metal ATPases before the appearance of eukaryots (Figure 1). Also, copper was probably not an essential trace element for early, anaerobic life forms. Cuproenzymes function almost exclusively in reactions involving oxygen (Figure 2), which only became available by a process which started approximately $10^{9}$ years ago. Copper would thus be a modern bioelement (Crichton \& Pierre 2001).

\section{Copper routing and regulation in $E$. hirae}

Figure 3 shows an overview of the copper circulation in E. hirae. Current evidence indicates that cupric copper, $\mathrm{Cu}(\mathrm{II})$, is converted to the cuprous form, $\mathrm{Cu}(\mathrm{I})$, at the $E$. hirae cell surface before being imported into the cell by the CopA $\mathrm{Cu}(\mathrm{I})$ ATPase (Wunderli-Ye \& Solioz 1998). The reductase has not been molecularly characterized.
Subsequent to coppers entry into the cell, it is routed in the cytoplasm by a specific carrier protein, the metallochaperone CopZ. The interaction of CopZ with the CopA ATPase has been characterized by surface plasmon resonance analysis (Multhaup et al. 2001). It has been hypothesized that $\mathrm{Cu}(\mathrm{I})$ entering the cell via the membrane portion of CopA is transferred to the N-terminal metal binding domain of CopA and subsequently passed forward to CopZ, which then routes the metal to the dimeric $\mathrm{Zn}$ (II)CopY (Fig. 3) (Cobine et al. 2002). CopY is a $\mathrm{Zn}$ containing homodimeric repressor $\left(1 \mathrm{Zn}^{2+} / 17 \mathrm{kDa}\right.$ monomer $)$ that binds to the promoter region of the cop operon, thereby repressing its own synthesis, as well as that of CopA, CopB and CopZ (Strausak \& Solioz 1997). Sequence alignment and homology modeling as well as preliminary NMR data (K. R. Poulsen, unpublished) suggest that CopY belongs to the family of winged-helix type repressors (Gajiwala \& Burley 2000). Other members of this family are the $\beta$-lactamase repressors MecI and BlaI (Melckebeke et al. 2003; Garcia-Castellanos et al. 2004; Wilke et al. 2004). Like most repressors, the CopY repressor is dimeric, with an apparent $M_{\mathrm{r}}$ of close to 50000 by gel filtration analysis (D. Strausak and M. Solioz, unpublished), suggesting it is in an extended conformation as commonly found in this

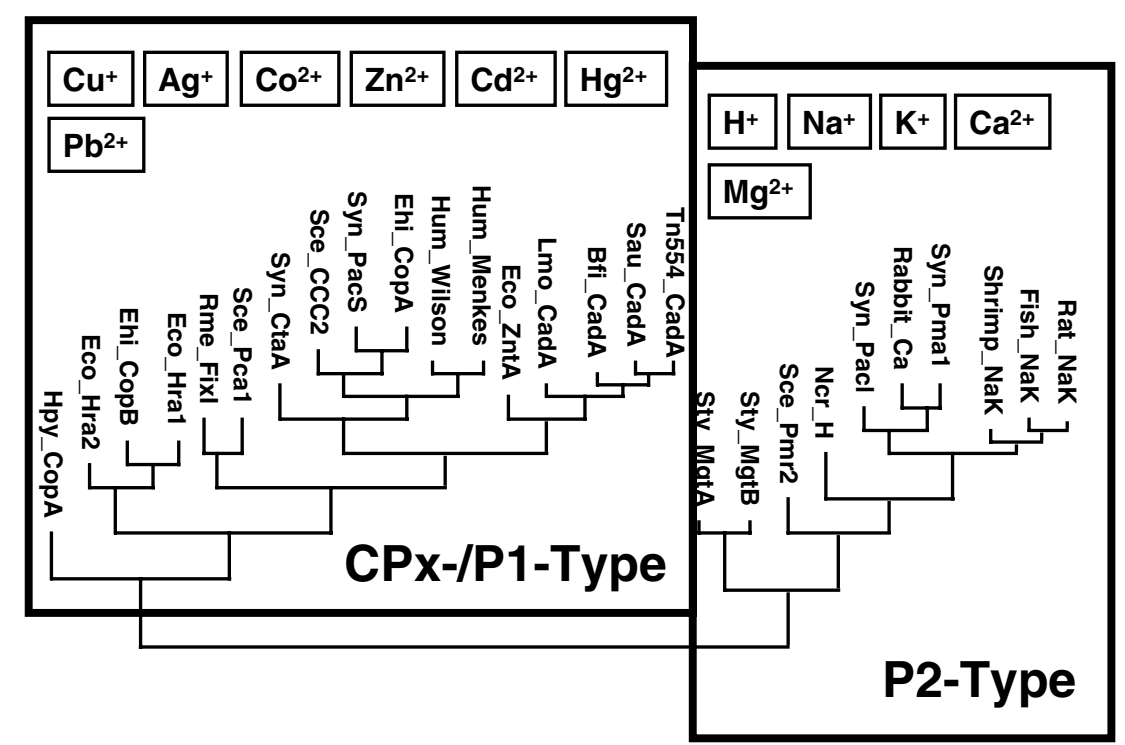

Figure 1. Unrooted phylogenetic tree of P-type ATPases. Divergence was scored for a selected sample of P-type and CPx-type ATPases by the Jukes-Cantor method (Swofford \& Olson 1990). Relationships between distant branches are not reliable. The rectangles delineate the subgroups of heavy metal transporting CPx-/P1-type ATPases and the non-heavy metal transporting P2-type ATPases. The ion specificities known for each group are indicated in the two fields. 


\begin{tabular}{|c|c|}
\hline Reduction State of $\mathrm{O}_{2}$ & $\begin{array}{l}\text { Relevance of Copper } \\
\mathrm{O}_{2} \text {-Transport by hemocyanin }\end{array}$ \\
\hline $\mathrm{O}_{2}^{--}+\mathrm{e}^{-}, 2 \mathrm{H}^{+}$ & Superoxide dismutase \\
\hline $\begin{array}{l}\mathrm{H}_{2} \mathrm{O}_{2} \\
\mathrm{Ie}^{-\mathrm{e}^{-}, \mathrm{H}^{+}} \\
-\mathrm{H}_{2} \mathrm{O}\end{array}$ & $\begin{array}{l}\text { Product of non-blue oxidases } \\
\text { (galactose and amine oxidases) }\end{array}$ \\
\hline но: & $\begin{array}{l}\text { Product of } \mathrm{H}_{2} \mathrm{O}_{2} \text { reduction by } \\
\text { Fenton-type reaction }\end{array}$ \\
\hline $\mathrm{H}_{2} \mathrm{O}$ & $\begin{array}{l}\text { Product of oxidations } \\
\text { (cyt. oxidases, blue oxidases) }\end{array}$ \\
\hline
\end{tabular}

Figure 2. Examples of the involvement of copper at different reduction states of oxygen.

family, whereas it actual molecular weight should be $2 \times 17000=34000 \mathrm{Da}$. Footprinting studies also support the proposal that the protein can have an extended conformation and further imply that the protein is a tail-to-tail dimer.

\section{Copper transfer from the chaperone to the repressor}

The copper transfer from $\mathrm{Cu}(\mathrm{I}) \mathrm{CopZ}$ to the CopZ repressor has been shown by a variety of techniques. By gel filtration analysis, it could be shown that in a mixture of $\mathrm{Cu}(\mathrm{I}) \mathrm{CopZ}$ and $\mathrm{Zn}$ (II)CopY, copper is quantitatively transferred to CopY and its zinc is released (Cobine et al.
1999). A copper-thiolate in a solvent-excluded environment displays luminescence. While $\mathrm{Cu}(\mathrm{I})$ $\mathrm{CopZ}$ is not luminescent, $\mathrm{Cu}(\mathrm{I})_{2} \mathrm{CopY}$ exhibits a strong luminescence. This shows that copper is transferred from a solvent exposed binding site on CopZ to a solvent excluded pocket in CopY. This copper transfer requires specific proteinprotein interaction. The second metal binding domain of the Menkes copper ATPase (MNKr2) could not transfer copper to CopY, although it has a structure similar to CopZ. However, CopZ has one very basic surface formed by four lysine residues and the $\mathrm{N}$-terminus, which is not present in MNKr2. If four lysine residues were inserted in similar positions into $\mathrm{MNKr}$ 2, a gain-of-function mutant which could donate copper to CopY could be generated. This suggests that a basic surface on the chaperone is required for the interaction of the chaperone with the repressor. For the interaction of the related yeast Atx1 chaperone, it could similarly be shown that a basic surface on Atx1 interacts with an acidic surface on its target protein, the copper ATPase CCC2 (Rosenzweig 2001).

\section{Repressor-DNA interaction: the cop-box}

Expression of the cop operon is low in standard growth media but can be induced up to 50 -fold by exposing the cells to extracellular copper.

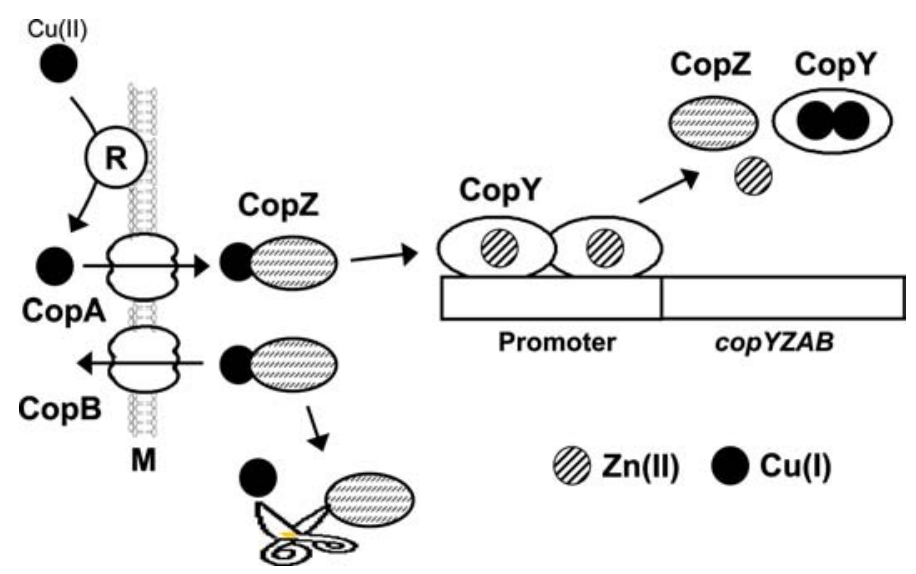

Figure 3. Model of copper circulation in E. hirae. A reductase (R) at the cytoplasmic membrane (M) reduces $\mathrm{Cu}(\mathrm{II})$ to $\mathrm{Cu}(\mathrm{I})$, which can be taken up by CopA. Copper is then transferred to the CopZ chaperone, which in turn donates it to the CopY repressor. Two $\mathrm{Cu}(\mathrm{I})$ per CopY monomer are transferred to the repressor, thereby releasing the bound zinc and releasing CopY from the promoter. This allows transcription of the four cop genes to proceed. Under high copper conditions, excess CopZ is degraded by a copperactivated protease. 
The CopY repressor binds to the consensus binding site TACANNTGTA, which was termed the 'cop-box' (Portmann et al. 2004) and suppresses transcription if no excess copper prevails in the cytoplasm. Mutation of the cop-box by sitedirected mutagenesis abolished the interaction with the repressor. Cop-boxes are also found in related bacteria such as Streptococcus mutans, Lactococcus lactis, or Lactobacillus sakei. All these organisms also contain CopY homologues which appear to regulate related copper homeostatic systems. The interaction of the E. hirae CopY repressor and those of the related bacteria mentioned above with the promoter were assessed in kinetic terms by surface plasmon resonance analysis. All homologous repressors exhibited essentially identical interaction kinetics with the E. hirae promoter, corroborating the universal nature of the cop-box. For the interaction of E. hirae CopY with its native promoter, association and dissociation constants for all the anticipated partial reactions could be derived (Figure 4).

Induction of the cop operon by excess copper thus proceeds by donation of two $\mathrm{Cu}(\mathrm{I})$ to
$\mathrm{Zn}$ (II)CopY. The resultant $\mathrm{Cu}(\mathrm{I})_{2} \mathrm{CopY}$ has an increased dissociation rate for the cop-box and an immeasurable association rate. CopY leaves the cop-box and allows transcription to proceed. In vitro, it proved impossible to return copper-loaded CopY to the zinc form and it appear likely that $\mathrm{Cu}(\mathrm{I})_{2} \mathrm{CopY}$ is degraded rather than recycled.

\section{Degradation of CopZ}

Under high copper conditions, the cop operon is induced and the level of the polycistronic cop mRNA increases up to $10^{3}$ fold (Lu \& Solioz 2001). However, the expression of the CopZ chaperone does not increase concomitantly. CopZ expression is highest at $0.75 \mathrm{mM}$ media copper and declines at higher copper concentrations (Figure 5a). It was argued that high $\mathrm{Cu}(\mathrm{I}) \mathrm{CopZ}$ concentrations could be toxic because the exposed copper could participate in Fenton-type reactions, thereby generating toxic radicals. Indeed, it was found that cells in which overexpression of CopZ was forced from a plasmid, became sensitive to oxidative stress by

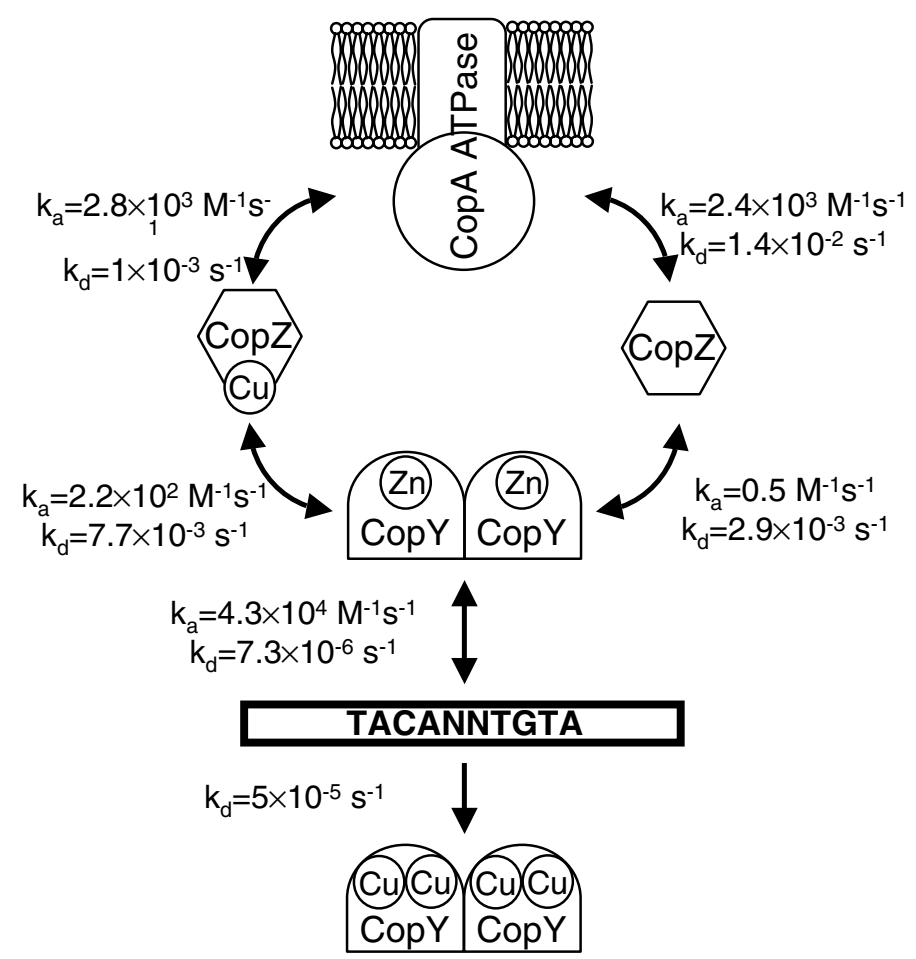

Figure 4. Overview of the interaction kinetics between elements of copper homeostasis and regulation in E. hirae. The kinetic values for the respective interactions are indicated. Values for the interaction of CopZ and $\mathrm{Cu}(\mathrm{I}) \mathrm{CopZ}$ with CopA were taken from Refs. Multhaup et al. (1996), Strausak et al. (1993), all other values are from Ref. Portman et al. (2004). 
paraquat or hydrogenperoxide. They also became markedly copper sensitive (Figure 5b). Degradation of CopZ or $\mathrm{Cu}(\mathrm{I}) \mathrm{CopZ}$ was found to be catalyzed by a copper induced protease, which could be detected in extracts of cells grown under high copper conditions (Figure 6). A major proteolytic activity was detected at an $\mathrm{M}^{\mathrm{r}}$ of around 58,000. This proteolytic activity was specific to CopZ as it did not react on gels containing bovine serum albumin or chicken egg lysozyme. In vitro degradation experiments with purified CopZ showed that the degradation of $\mathrm{Cu}(\mathrm{I}) \mathrm{CopZ}$ was faster than that of apoCopZ, with half-times of degradation of 7 and 22 min respectively.

\section{Conclusion}

The study of the copper homeostasis in E. hirae has yielded important insight into the molecular mechanism of copper regulation and a number of new concepts have emerged. It has allowed to extensively
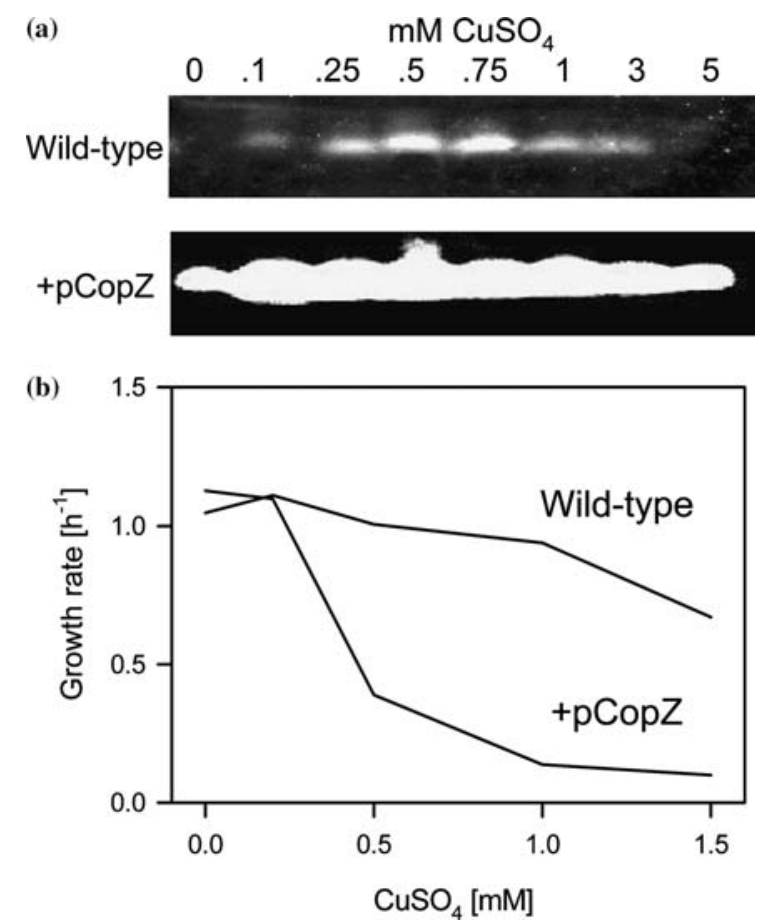

Figure 5. Inhibitory effect of CopZ overexpression. (a) Western blot showing CopZ levels of wild-type cells or cells containing a CopZ overexpressing plasmid (+ pCopZ) grown at different copper concentrations. (b) Growth rates of wild-type and CopZ overexpressing $(+\mathrm{pCopZ})$ cells as a function of the media copper concentration.

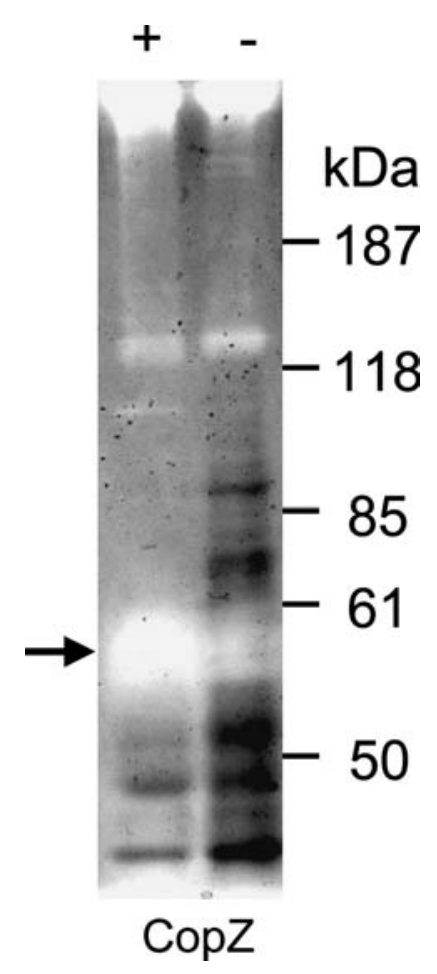

Figure 6. Zymogram of CopZ proteolytic activity. The presence of a copper dependent proteases was detected by zymography. Extracts $(50 \mu \mathrm{g} /$ lane $)$ from cells induced with $3 \mathrm{mM}$ copper $(+)$ or from uninduced cells $(-)$ were resolved on a $7.5 \%$ SDS polyacrylamide gel, renatured and allowed to reacts with the CopZ embedded in the gel. The vertical scale shows the migration of standards of the corresponding molecular weights in $\mathrm{kDa}$ and the arrow the major CopZ-proteolytic activity.

characterize the function of the CopZ chaperone in delivering $\mathrm{Cu}(\mathrm{I})$ to the $\mathrm{CopY}$ repressor. This is a novel induction mechanism whereby the inducer is delivered to the repressor by a protein. Surface plasmon resonance analysis of the repressor-DNA interaction has been used to identify the novel copbox as the consensus binding sequence and as a widespread DNA motif in copper regulation by Gram-positive bacteria. A complete set of kinetic constants could be derived for the CopA-CopZCopY-DNA interaction chain. Finally, the copper dependent degradation of CopZ is a novel mechanism in copper homeostatic regulation.

\section{Acknowledgements}

Part of this work was supported by Grant 3168075.02 from the Swiss National Foundation and by a grant from the International Copper Association. 


\section{References}

Cobine P, Wickramasinghe WA, Harrison MD, Weber T, Solioz M, Dameron CT. 1999 The Enterococcus hirae copper chaperone CopZ delivers copper(I) to the CopY repressor. FEBS Lett 445, 27-30.

Cobine PA, George GN, Jones CE, Wickramasinghe WA, Solioz M, Dameron CT. 2002 Copper transfer from the $\mathrm{Cu}$ (I) chaperone, CopZ, to the repressor, Zn(II)CopY: Metal coordination environments and protein interactions. Biochemistry 41, 5822-5829.

Crichton RR, Pierre J-L. 2001 Old iron, young copper: from Mars to Venus. Biometals 14, 99-112.

Gajiwala KS, Burley SK. 2000 Winged helix proteins. Curr Opin Struct Biol 10, 110-116.

Garcia-Castellanos R, Mallorqui-Fernandez G, Marrero A, Potempa J, Coll M, Gomis-Ruth FX. 2004 On the transcriptional regulation of methicillin resistance: MecI repressor in complex with its operator. J Biol Chem 279, 17888-17896.

Lu ZH, Dameron CT, Solioz M. 2003 The Enterococcus hirae paradigm of copper homeostasis: copper chaperone turnover, interactions, and transactions. Biometals 16, 137-143.

Lu ZH, Solioz M. 2001 Copper-induced proteolysis of the CopZ copper chaperone of Enterococcus hirae. J Biol Chem 276, 47822-47827.

Lu ZH, Solioz M. 2002 Bacterial copper transport. Adv Protein Chem 60, 93-121.

Lutsenko S, Kaplan JH. 1995 Organization of P-type ATPases: significance of structural diversity. Biochemistry 34, 1560715613.

Melckebeke HV, Vreuls C, Gans P, Filee P, Llabres G, Joris B, Simorre JP. 2003 Solution structural study of BlaI: implications for the repression of genes involved in beta-lactam antibiotic resistance. $J$ Mol Biol 333, 711-720.

Multhaup G, Schlicksupp A, Hesse L, Beher D, Ruppert T, Masters CL, Beyreuther K. 1996 The amyloid precursor protein of Alzheimers disease in the reduction of copper(II) to copper(I). Science 271, 1406-1409.

Multhaup G, Strausak D, Bissig K-D, Solioz M. 2001 Interaction of the CopZ copper chaperone with the CopA copper ATPase of Enterococcus hirae assessed by surface plasmon resonance. Biochem Biophys Res Commun 288, 172-177.

Odermatt A, Solioz M. 1995 Two trans-acting metalloregulatory proteins controlling expression of the copper-ATPases of Enterococcus hirae. J Biol Chem 270, 4349-4354.

Odermatt A, Krapf R, Solioz M. 1994 Induction of the putative copper ATPases, CopA and CopB, of Enterococcus hirae by $\mathrm{Ag}^{+}$and $\mathrm{Cu}^{2+}$, and $\mathrm{Ag}^{+}$extrusion by CopB. Biochem Biophys Res Commun 202, 44-48.

Odermatt A, Suter H, Krapf R, Solioz M. 1993 Primary structure of two P-type ATPases involved in copper homeostasis in Enterococcus hirae. J Biol Chem 268, 12775-12779.
Portmann R, Magnani D, Stoyanov JV, Schmechel A, Multhaup G, Solioz M. 2004 Interaction kinetics of the copperresponsive CopY repressor with the cop promoter of Enterococcus hirae. J Biol Inorg Chem 9, 396-402.

Rasmussen B. 2000 Filamentous microfossils in a 3,235-millionyear-old volcanogenic massive sulphide deposit. Nature $\mathbf{4 0 5}$, 676-679.

Rosenzweig AC. 2001 Copper delivery by metallochaperone proteins. Acc Chem Res 34, 119-128.

Solioz M. 2001 Bacterial copper transport. In: Winkelmann G (Ed.), Microbial Transport Systems. Wiley; Weinheim: pp. 361-376.

Solioz M., Stoyanov JV. 2002 How cells deal with copper a lesson from bacteria. In: Anke M, Mller R, Schäfer U, Stoeppler M, eds. Macro and Trace Elements.. SchubertVerlag; Leipzig: pp. 485-492.

Solioz M, Stoyanov JV. 2003 Copper homeostasis in Enterococcus hirae. FEMS Microbiol Rev 27, 183-196.

Solioz M, Vulpe C. 1996 CPx-type ATPases: a class of P-type ATPases that pump heavy metals. Trends Biochem Sci 21, 237-241.

Strausak D, Solioz M. 1997 CopY is a copper-inducible repressor of the Enterococcus hirae copper ATPases. J Biol Chem 272, 8932-8936.

Strausak D, Waser M, Solioz M. 1993 Functional expression of the Enterococcus hirae $\mathrm{NaH}$-antiporter in Escherichia coli. $J$ Biol Chem 268, 26334-26337.

Swofford DL, Olson PD. 1990 Phylogeny reconstruction. In: Hillis DM, Moritz C, eds. Molecular Systematics. Sinauer Associates, Inc.; 21-132.

Wilke MS, Hills TL, Zhang HZ, Chambers HF, Strynadka NC. 2004 Crystal structures of the apo and penicillin-acylated forms of the BlaR1 beta-lactam sensor of Staphylococcus aureus. J Biol Chem 279, 47278-47287.

Wimmer R, Dameron CT, Solioz M. 2002 Molecular hardware of copper homeostasis in Enterococcus hirae. In: Massaro EJ, eds. Handbook of Copper Pharmacology and Toxicology. Humana Press; Totowa NJ: pp. 527-542.

Wunderli-Ye H, Solioz M. 1998 Regulation of the cop operon of Enterococcus hirae by the CopY repressor and copper. In: Collery P, Brätter P, Negrettide Brätter V, Khassanova L, Etienne J-C, eds. Metal Ions in Biology and Medicine. John Libbey Eurotext; Paris: pp. 109-113.

Wunderli-Ye H, Solioz M. 1999 Effects of promoter mutations on the in vivo regulation of the cop operon of Enterococcus hirae by copper(I) and copper(II). Biochem Biophys Res Commun 259, 443-449.

Zierenberg RA, Adams MW, Arp AJ. 2000 Life in extreme environments: hydrothermal vents. Proc Natl Acad Sci USA 97, 12961-12962. 